\title{
Do tratamento compulsório à ética do vínculo
}

\author{
From compulsory treatment toward the ethics of the bond \\ Del tratamiento obligatorio a la ética del vínculo
}

Ricardo Rodrigues Teixeira ${ }^{(\mathrm{a})}$

O artigo em debate traz uma instigante reflexão a respeito do tratamento compulsório, tema tanto mais relevante quanto não se aplica apenas ao caso específico da tuberculose, mas a algumas outras condições médico-sanitárias. Segundo o autor, a jurisprudência estabelecida entende que o traço comum a todas elas, conforme consta nesta ação do Ministério Público, "é a impossibilidade de o enfermo se opor ao tratamento, devido à certeza de sua periculosidade para a sociedade, pois, neste caso, o interesse público é colocado antes do seu interesse pessoal". Partindo dessa constatação, o autor oferece uma valiosa reflexão sobre diferentes sentidos de justiça, com a qual procurarei estabelecer um breve diálogo.

Preliminarmente, penso ser vantajoso distinguir entre diferentes modalidades de tratamento compulsório. Não fica inteiramente claro, no artigo, se ele está se referindo sempre à "internação involuntária", nem se poderíamos considerar o DOTS ("tratamento diretamente observado") como uma modalidade de tratamento compulsório. Isso é importante, pois existem diferenças significativas entre as duas modalidades, tanto no caso da TB, quanto nas outras condições (como os mencionados transtornos mentais e uso abusivo de álcool e outras drogas) em que pacientes têm sido sentenciados ao tratamento forçado. No caso destas últimas, ocorrem os dois tipos de decisões judiciais: tanto o tratamento obrigatório em regime de internação, quanto em regime ambulatorial. Por outro lado, entendo que o fato de o DOTS ser uma recomendação técnica de especialistas não o faria menos "compulsório" do que o tratamento imposto por uma decisão judicial.

Contudo, mesmo tendo em comum o caráter forçado do tratamento, há uma diferença não desprezível entre ele se dar em situação de confinamento ou não. Diferenças não apenas éticas e jurídicas, mas, também, na consideração de certos "paradoxos" identificados na posição de alguns especialistas, quando defendem a "tese da internação involuntária" após esgotadas todas as medidas de tratamento em liberdade. O autor questiona: que sentido faria tornar compulsória a "adesão" do paciente a serviços que já se provaram inefetivos em conseguir tratá-los? Bem, não há paradoxo se o que estão defendendo é a "tese da internação involuntária", isto é, o tratamento forçado em "regime fechado" (neste caso, o que caberia discutir é quanto essa medida pode

(a) Departamento de Medicina Preventiva, Faculdade de Medicina, Universidade de São Paulo. Av. Dr. Arnaldo 455, $2^{\circ}$ andar. São Paulo, SP, Brasil. 01246-903. ricarte@usp.br 
aprofundar a inefetividade dos serviços, uma vez que promove a "estigmatização e a vitimização dos pacientes de tuberculose", minando a confiança e afastando ainda mais estes pacientes dos serviços. E sendo um efeito dessa medida que se produz em escala social, o verdadeiro paradoxo seria o de uma decisão judicial que, pretendendo se assentar na primazia do interesse coletivo, produz efeitos nefastos exatamente neste nível). Por outro lado, certamente é um paradoxo se o tratamento forçado for ambulatorial, uma vez que, neste caso, o serviço já teria, de fato, falhado em conseguir o tratamento em "regime aberto" (neste caso, o importante seria examinar em maior detalhe o significado do dispositivo DOTS enquanto uma modalidade de tratamento compulsório, garantido pela observação diária e direta da tomada do medicamento pelos pacientes. Fundamentalmente, interessanos examinar os efeitos deste dispositivo sobre os possíveis sucessos ou insucessos dos serviços em conseguir tratar pacientes de tuberculose em liberdade).

Aprofundando um pouco mais o exame dessa diferença, valho-me de uma inspiração deleuziana a partir da obra de Foucault': a diferença entre um dispositivo "disciplinar" (internação) e um dispositivo de "controle" (observação direta). Enquanto o primeiro opera segundo a lógica das "instituições totais" 2 e, evidentemente, oferece menos possibilidades de se produzirem linhas de fuga (quase que a única linha de fuga seria, literalmente, a fuga do espaço de confinamento), o segundo possui a ambivalência da maior parte dos dispositivos de "controle a céu aberto", oferecendo maiores chances de se fazer outra coisa na/da situação por ele imposta, com todas as possibilidades de reinvenção das relações que se dão numa longa e continuada sucessão de encontros diários, ainda que motivados pela finalidade precípua de apenas observar e garantir (modo brando de obrigar) a tomada dos medicamentos pelo paciente.

É a partir dessa possibilidade de "reinvenção das relações" que passo ao ponto que me parece mais fundamental a ser enfatizado neste debate: numa palavra, o tema do vínculo.

Como a não-adesão ao tratamento é a justificativa de base para o tratamento compulsório, o autor não deixa de abordar o problema, fazendo importantes observações. Aponta uma constelação de expressões cercando o tema da adesão - "fracasso", "abandono", "recalcitrância", "desobediência insistente" dos pacientes - que não apenas revelam concepções subjacentes, mas que produzem efeitos cognitivos e morais. São "dispositivos linguísticos" que acionam, pragmaticamente, mecanismos de culpabilização.

Outra poderia ser a abordagem desse problema se nos deslocássemos de uma perspectiva na qual os serviços são vistos como locais de "ofertas tecnológicas" às quais os pacientes adeririam ou não, segundo os ditames da sua vontade individual, para uma perspectiva na qual o que está em questão é a capacidade de esses serviços se constituírem como "autênticos ambientes de troca", produzindo vínculos efetivos com seus usuários. Outra seria a abordagem do problema da "adesão" (que sequer mereceria ser tratado por este termo), se o foco se deslocasse da culpabilização dos pacientes para o desafio de estruturar serviços que invistam na construção de vínculo, confiança e corresponsabilidade.

Simetricamente, esse deslocamento de perspectiva se faz acompanhar de um deslocamento nos sentidos de justiça, segundo a tipologia apresentada pelo autor. Desloca-se do sentido de justiça como "reparação" ("contrapesar um dano cometido por um ator social a outro ator social"), no qual estaria baseada a defesa do tratamento compulsório, ao sentido relacionado ao fato de que uma sociedade é "tanto mais justa quanto mais intensa for a força de sua 'coesão social'."

A relação deste sentido de justiça com o desafio da construção do vínculo nos serviços de saúde é bastante evidente. Pode-se imaginar sua propensão a produzir uma outra jurisprudência, que, ao invés de culpabilizar os pacientes, sentenciando-os ao tratamento compulsório, imputaria a responsabilidade primordial aos próprios serviços, afirmando seu compromisso ineludível com a produção de graus maiores de "coesão social". Uma espécie de sentido spinozano de justiça, já que este filósofo identifica a criação e ampliação de direitos à produção coletiva de potência, por meio de bons encontros e de arranjos sociais propiciadores de bons encontros ${ }^{3}$.

Essa possibilidade de se repensar o cuidado dos pacientes com tuberculose que, por múltiplos motivos, resistem ao tratamento, considerando diferentes sentidos de justiça - sentidos que não sendo captados pela "operação formal do direito", dependem, igualmente, de "outras valorações éticas" - é, sem dúvida, uma virtuosa contribuição do autor para o debate. 


\section{Referências}

1. Deleuze G. Foucault. São Paulo: Brasiliense; 2005.

2. Goffman E. Manicômios, prisões e conventos. São Paulo: Perspectiva; 2008.

3. Spinoza B. Ética. Belo Horizonte: Autêntica; 2007.

Recebido em 13/04/16. Aprovado em 15/04/16. 